Article

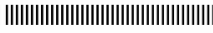

\title{
Caesium Uptake in Mushroom - Comparison with Coexisting Elements and Effect of Ammonium Ion as a Competitor, by Laboratory Experiments Using Hebeloma vinosophyllum -
}

\author{
Quyen Bao-Thuy Ho*,**, Satoshi YoshIDA*** and Akira SuzUKI****,***** \\ * Graduate School of Horticulture, Chiba University \\ 648 Matsudo, Matsudo-shi, Chiba Pref. 271-8510, Japan \\ **Faculty of Biology, University of Science, Vietnam National University Ho Chi Minh City \\ 227 Nguyen Van $\mathrm{Cu}$, District 5, Ho Chi Minh City, Vietnam \\ ***National Institute of Radiological Sciences \\ 4-9-1 Anagawa, Inage-ku, Chiba-shi, Chiba Pref. 263-8555, Japan \\ ****Faculty of Education, Chiba University \\ 1-33 Yayoi-cho, Inage-ku, Chiba-shi, Chiba Pref. 263-8522, Japan \\ ***** Graduate School of Horticulture, Chiba University \\ 648 Matsudo, Matsudo-shi, Chiba Pref. 271-8510, Japan
}

Received November 15, 2012

\begin{abstract}
An ectomycorrhizal ammonia fungus Hebeloma vinosophyllum was cultivated in the Ohta's liquid medium with $\mathrm{Cs}$ and different concentrations of $\mathrm{NH}_{4}{ }^{+}$. This fungus absorbed caesium and coexisting elements $(\mathrm{K}, \mathrm{Ca}, \mathrm{Mg}$, $\mathrm{Zn}, \mathrm{Cu}, \mathrm{Fe}$ and $\mathrm{P})$ with the highly transfer factors. The highest translocation from mycelium to fruit body was observed in Cs among 8 analysed elements. The uptake of $\mathrm{Cs}$ might have a similar pattern to those of $\mathrm{K}$ and $\mathrm{P}$. However, the high concentration of $\mathrm{NH}_{4}{ }^{+}$might affect as the competitor to the uptake of both $\mathrm{Cs}$ and $\mathrm{K}$, but not to the uptake of $\mathrm{P}$. The addition of $\mathrm{NH}_{4}{ }^{+}$affected more the uptake of $\mathrm{Cs}$ than that of $\mathrm{K}$.
\end{abstract}

Key Words : mushroom, caesium, stable elements, potassium, ammonium ion, uptake, translocation, fruit body, mycelium, in vitro experiment

\section{Introduction}

After the accident of Fukushima Daiichi Nuclear Power Plant in 2011 in Japan, relatively high concentrations of radiocaesium were reported in wild mushrooms from environmental monitoring and food monitoring programs. The concentrations exceeded the food regulation (100 Bq/kg as total radiocaesium) were sometimes observed even in wood $\log$ cultivated mushroom (Lentinula edodes). It is quite important to understand the mechanism of radiocaesium uptake by mushrooms, in order to control and to regulate the radiocaesium concentra- tions in mushrooms.

It is known that, mushrooms tend to accumulate caesium, including radiocaesium in nature. $^{1)-3)}$ The concentrations of caesium and radiocaesium in mushrooms are higher than those in plants. ${ }^{2)}{ }^{-6)}$

The Chernobyl accident resulted in the high concentration of radiocaesium in mushrooms collected in European forests. ${ }^{7)-11)}$ Accumulation of radiocaesium derived from atmospheric nuclear weapon testing in mushrooms was also reported in Japanese forests before the accident of Fukushima Daiichi Nuclear Power Plant. $^{2)}{ }^{-6), 12)}$ 
Many factors controlling the radiocaesium concentration in mushrooms such as type of forests ${ }^{13)}$, soil $\mathrm{pH}^{14)}$ and species of mushrooms ${ }^{15)}$, have been discussed. The relationship between the habitat of the mycelium and the radiocaesium concentration in the fruit body has also been studied. ${ }^{6), 16)}$ Some researches indicated the role of mycelium on the accumulation of radiocaesium in surface soils. ${ }^{17)}{ }^{18)}$ Nevertheless, the detailed mechanism of radiocaesium uptake in mushrooms has not yet thoroughly known.

On the other hand, chemical behaviour of radiocaesium is expected to be similar to that of stable caesium. Rühm et al. ${ }^{19)}$ and Yoshida et al. $^{20), 21)}$ summarized the relationship between radiocaesium and stable caesium in mushrooms collected from forest ecosystems. The ${ }^{137} \mathrm{Cs} / \mathrm{Cs}$ ratios were fairly constant for samples collected at the same site. From these findings, they suggested the possible use of stable elements for predicting radionuclide transport.

During survey of the radiocaesium accumulation in mushrooms collected from Japanese forests, the high concentration of ${ }^{137} \mathrm{Cs}$ was observed in several Hebeloma species. ${ }^{6}$ In laboratory experiment (in vitro), the ${ }^{137} \mathrm{Cs}$ accumulation by mycelium of an ectomycorrhizal ammonia fungus Hebeloma vinosophyllum was affected by monovalent cations, such as $\mathrm{K}^{+}$and $\mathrm{NH}_{4}{ }^{+}$, in the media. ${ }^{22)}$ The uptake of ${ }^{137} \mathrm{Cs}$ by the mycelium of the mushroom Pleurotus ostreatus decreased with increasing of $\mathrm{Cs}, \mathrm{K}$ or $\mathrm{Rb}$ concentration in the YMG media. ${ }^{23)}$ Effects of coexisting elements as well as ammonium ion, however, on the radiocaesium accumulation in mushrooms, especially quantity in both mycelium and fruit bodies, have not been well examined.

Therefore, the Cs uptake from medium and accumulation in mushroom (mycelium and fruiting bodies) were investigated by the model of fruiting on the liquid medium under the competition of $\mathrm{NH}_{4}{ }^{+}$in this study. The absorbing abilities of coexisting elements $(\mathrm{K}, \mathrm{Ca}, \mathrm{Mg}, \mathrm{Zn}$, $\mathrm{Cu}, \mathrm{Fe}$ and $\mathrm{P}$ ) by the mushroom were also investigated. Considering easily fruiting ability of H. vinosophyllum, it was selected as a model organism for our investigation of the Cs absorption of ectomycorrhizal fungi.

\section{Experimental}

H. vinosophyllum HCMUS-C2 ${ }^{24)}$ was pre-cultivated on MY agar medium [malt extract 10 $\mathrm{g} / \mathrm{L}$ (Difco, Detroit, USA), yeast extract $2 \mathrm{~g} / \mathrm{L}$ (Difco, Detroit, USA) and agar $15 \mathrm{~g} / \mathrm{L}$ (Nacalai Tesque, Kyoto, Japan)] in a petri dish.

H. vinosophyllum inoculum disks were cut with a $4 \mathrm{~mm}$-diameter cork border from the sub-peripheral regions of actively growing colonies and placed into $100 \mathrm{~mL}$ of the Ohta's liquid medium ${ }^{25)}$ in a $200 \mathrm{~mL}$ flask, incubated at $25.0^{\circ} \mathrm{C}$ $\pm 0.5^{\circ} \mathrm{C}$, in $12 \mathrm{hr} / 12 \mathrm{hr}$ of the dark/light regime with a white fluorescent lamp (Hitachi, Tokyo, Japan), providing a light intensity at $4.56 \mu \mathrm{mol}$ $\mathrm{m}^{-2} \mathrm{~s}^{-1}$. The $\mathrm{pH}$ of the medium was adjusted to 7.0 with $1 \mathrm{M} \mathrm{KOH}$. Five flasks for each treatment were prepared.

In comparison between the Cs uptake and coexisting elements uptake, $H$. vinosophyllum was inoculated in the Ohta's liquid medium added $\left(\mathrm{NH}_{4}\right)_{2} \mathrm{SO}_{4}$ as a nitrogen source with the concentration $177 \mathrm{mg} \mathrm{NH}_{4}{ }^{+} / \mathrm{L}$. Concentrations and chemical forms of $\mathrm{Cs}, \mathrm{K}, \mathrm{Ca}, \mathrm{Mg}, \mathrm{Zn}, \mathrm{Cu}, \mathrm{Fe}$ and $\mathrm{P}$ in the medium were shown in Table 1.

In order to investigate the effect of coexisting $\mathrm{NH}_{4}{ }^{+}$on the uptake of $\mathrm{Cs}, \mathrm{K}$ and $\mathrm{P}$ by $H$. vinosophyllum, $\left(\mathrm{NH}_{4}\right)_{2} \mathrm{SO}_{4}$ was added to the Ohta's liquid media with different concentrations of $\mathrm{NH}_{4}{ }^{+}(177 \mathrm{mg} / \mathrm{L}, 590 \mathrm{mg} / \mathrm{L}$ and 1770 
Table 1 Concentrations and chemical forms of $\mathrm{Cs}$ and coexisting elements ( $\mathrm{K}, \mathrm{Ca}, \mathrm{Mg}, \mathrm{Zn}, \mathrm{Cu}, \mathrm{Fe}$ and $\mathrm{P}$ ) in the medium

\begin{tabular}{lcl}
\hline Element & Concentration $(\mathrm{mg} / \mathrm{L})$ & $\mathrm{Chemical}$ form \\
\hline $\mathrm{Cs}$ & 1 & $\mathrm{CsCl}$ \\
$\mathrm{K}$ & 1106 & $\mathrm{KH}_{2} \mathrm{PO}_{4}$ and $\mathrm{KOH}$ \\
$\mathrm{Ca}$ & 13.6 & $\mathrm{CaCl}_{2}$ \\
$\mathrm{Mg}$ & 97.4 & $\mathrm{MgSO}_{4}$ \\
$\mathrm{Zn}$ & 0.68 & $\mathrm{ZnSO}_{4}$ \\
$\mathrm{Cu}$ & 0.25 & $\mathrm{CuSO}_{4}$ \\
$\mathrm{Fe}$ & 17.3 & $\mathrm{FeCl}_{3}$ \\
$\mathrm{P}$ & 227.8 & $\mathrm{KH}_{2} \mathrm{PO}_{4}$ \\
\hline
\end{tabular}

Table 2 Concentrations of $\mathrm{K}$ in media added different concentrations of $\mathrm{NH}_{4}{ }^{+}$

\begin{tabular}{cc}
\hline $\begin{array}{c}\text { Concentration of } \mathrm{NH}_{4}{ }^{+} \\
\text {in medium }(\mathrm{mg} / \mathrm{L})\end{array}$ & $\begin{array}{c}\text { Concentration of K } \\
\text { in medium }(\mathrm{mg} / \mathrm{L})\end{array}$ \\
\hline 177 & 1106 \\
590 & 1129 \\
1770 & 1145 \\
\hline
\end{tabular}

$\mathrm{mg} / \mathrm{L})$. The concentration of $\mathrm{K}$ was changed in different media (Table 2) due to the $\mathrm{pH}$ adjustment of medium to 7 by $1 \mathrm{M} \mathrm{KOH}$.

H. vinosophyllum formed fruit bodies after about one month of inoculation. The mycelium and the fruit bodies were collected and dried at $60^{\circ} \mathrm{C}$. The dry samples were digested in Teflon ${ }^{\mathrm{TM}}$ PFA pressure decomposition vessels with acids $\left(\mathrm{HNO}_{3}, \mathrm{HF}\right.$ and $\left.\mathrm{HClO}_{4}\right)$ at about $120^{\circ} \mathrm{C}$ for one day. Then, the samples were evaporated to dry and the residues were dissolved in $2 \% \mathrm{HNO}_{3}$.

The trace elements ( $\mathrm{Cs}, \mathrm{Zn}$ and $\mathrm{Cu}$ ) were measured by ICP-MS (Agilent 7500a, Agilent Technologies Inc., Tokyo, Japan). The major elements ( $\mathrm{K}, \mathrm{P}, \mathrm{Ca}, \mathrm{Mg}$ and $\mathrm{Fe}$ ) were determined by ICP-AES (VISTA-PRO, Seiko Instruments Inc., Chiba, Japan). Internal standards $\mathrm{Rh}$, In and $\mathrm{Bi}$ were used to compensate for changes in analytical signals during the operation. Details of the analyses were described in Yoshida and Muramatsu. ${ }^{26)}$
The mean values of the five flasks were calculated. The transfer factors ( $\mathrm{L} / \mathrm{kg}$ dry) of $\mathrm{Cs}$ and coexisting elements were defined as their concentrations $(\mathrm{mg} / \mathrm{kg}$ dry) in dry samples (mycelium or fruit bodies) divided by their concentrations $(\mathrm{mg} / \mathrm{L})$ in the medium at the beginning of the experiment. The translocations of Cs and coexisting elements from the mycelium to the fruit bodies were determined as their concentrations in the fruit bodies divided by those in the mycelium.

\section{Results and Discussion}

3.1 The uptake of caesium and coexisting elements by Hebeloma vinosophyllum

The $\mathrm{Cs}$ and coexisting elements $(\mathrm{K}, \mathrm{Ca}, \mathrm{Mg}$, $\mathrm{Zn}, \mathrm{Cu}, \mathrm{Fe}$ and $\mathrm{P}$ ) uptakes of the mycelium and the fruit bodies were shown as concentration ( $\mathrm{mg} / \mathrm{kg}$ dry sample) in Table 3 and transfer factors in Fig. 1. All samples had mean transfer factors higher than $20 \mathrm{~L} / \mathrm{kg}$ dry.

In the mycelium, the transfer factors were in 
Table 3 Concentration ( $\mathrm{mg} / \mathrm{kg}$ dry sample) of $\mathrm{Cs}, \mathrm{K}, \mathrm{Ca}, \mathrm{Mg}$, $\mathrm{Zn}, \mathrm{Cu}, \mathrm{Fe}$ and $\mathrm{P}$ in mycelium and fruit bodies of Hebeloma vinosophyllum

\begin{tabular}{lcc}
\hline Element & Mycelium & Fruit bodies \\
\hline $\mathrm{Cs}$ & $2.33^{*} 10^{1} \pm 1.10^{*} 10^{0}$ & $5.02^{*} 10^{1} \pm 1.10^{*} 10^{0}$ \\
$\mathrm{~K}$ & $2.90^{*} 10^{4} \pm 2.48^{*} 10^{3}$ & $4.95 * 10^{4} \pm 5.18^{*} 10^{3}$ \\
$\mathrm{Ca}$ & $6.68 * 10^{2} \pm 1.38^{*} 10^{2}$ & $6.00^{*} 10^{2} \pm 1.25 * 10^{2}$ \\
$\mathrm{Mg}$ & $2.13 * 10^{3} \pm 3.09 * 10^{2}$ & $2.25 * 10^{3} \pm 2.77 * 10^{2}$ \\
$\mathrm{Zn}$ & $7.04 * 10^{1} \pm 2.32 * 10^{1}$ & $5.96 * 10^{2} \pm 1.24 * 10^{1}$ \\
$\mathrm{Cu}$ & $4.63 * 10^{1} \pm 6.80^{*} 10^{0}$ & $1.29 * 10^{1} \pm 2.70^{*} 10^{0}$ \\
$\mathrm{Fe}$ & $1.46 * 10^{3} \pm 3.07 * 10^{2}$ & $5.88^{*} 10^{2} \pm 1.38^{*} 10^{2}$ \\
$\mathrm{P}$ & $8.34 * 10^{3} \pm 3.65^{*} 10^{2}$ & $1.31^{*} 10^{4} \pm 2.23 * 10^{3}$ \\
\hline
\end{tabular}

Mean \pm standard deviation

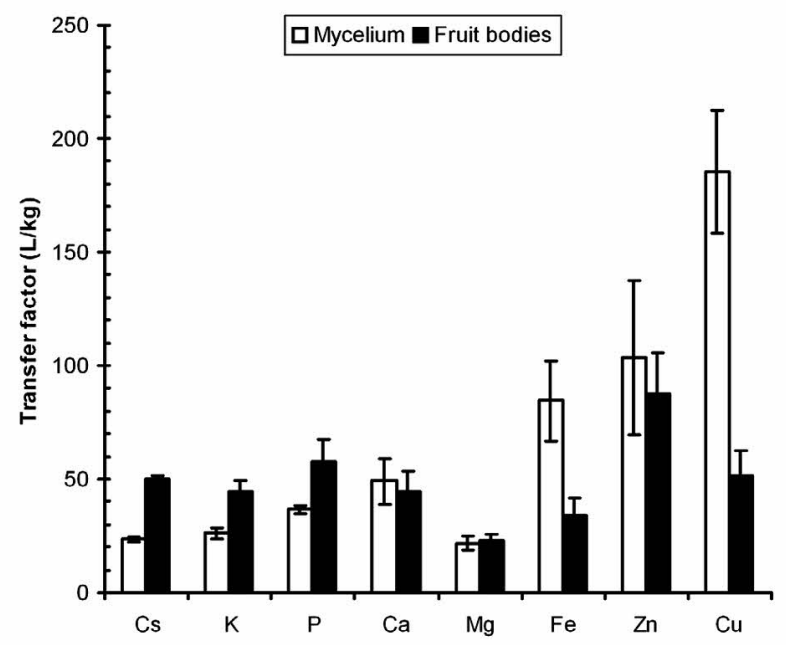

Fig. 1 The transfer factors of $\mathrm{Cs}, \mathrm{K}, \mathrm{P}, \mathrm{Ca}, \mathrm{Mg}, \mathrm{Fe}, \mathrm{Zn}$ and $\mathrm{Cu}$ in Hebeloma vinosophyllum biomass (mycelium and fruit bodies). Mean \pm standard deviation (vertical bar).

order of $\mathrm{Cu}>\mathrm{Zn}>\mathrm{Fe}>\mathrm{Ca}>\mathrm{P}>\mathrm{K}>\mathrm{Cs}>\mathrm{Mg}$. The transfer factors of $\mathrm{Cu}$ and $\mathrm{Zn}$ were markedly higher than $100 \mathrm{~L} / \mathrm{kg}$ dry.

In the fruit bodies, the different order of transfer factors were observed as $\mathrm{Zn}>\mathrm{P}>\mathrm{Cu}$ $>\mathrm{Cs}>\mathrm{K}>\mathrm{Ca}>\mathrm{Fe}>\mathrm{Mg}$. The transfer factor of Zn was the highest $(87.6 \mathrm{~L} / \mathrm{kg}$ dry). These results showed that $H$. vinosophyllum tended to highly accumulate $\mathrm{Zn}, \mathrm{P}, \mathrm{Cu}$ and $\mathrm{Cs}$ in fruit bodies with the transfer factors higher than 50 L/kg dry.
The highest translocation from the mycelium to the fruit bodies (2.2) was observed in Cs. The translocations of $\mathrm{Cs}, \mathrm{K}$ and $\mathrm{P}$ were much higher than 1 , while those of $\mathrm{Ca}, \mathrm{Mg}$ and $\mathrm{Zn}$ were approximately equal to 1 . The translocations of $\mathrm{Cu}$ and $\mathrm{Fe}$ from mycelium to fruit bodies were lower than 1 (Table 4).

$\mathrm{Cs}, \mathrm{K}$ and $\mathrm{P}$ concentrations in the fruit bodies were higher than those in the mycelium, while $\mathrm{Ca}$ and $\mathrm{Mg}$ concentrations in the fruit bodies approximated to those in the mycelium. Con- 
Table 4 Translocation of $\mathrm{Cs}, \mathrm{K}, \mathrm{P}, \mathrm{Ca}, \mathrm{Mg}, \mathrm{Fe}, \mathrm{Zn}$ and $\mathrm{Cu}$ in Hebeloma vinosophyllum from mycelium to fruit bodies

\begin{tabular}{cc}
\hline Element & Translocation from mycelium to fruit bodies \\
\hline $\mathrm{Cs}$ & 2.2 \\
$\mathrm{~K}$ & 1.7 \\
$\mathrm{Ca}$ & 0.9 \\
$\mathrm{Mg}$ & 1.1 \\
$\mathrm{Zn}$ & 0.8 \\
$\mathrm{Cu}$ & 0.3 \\
$\mathrm{Fe}$ & 0.4 \\
$\mathrm{P}$ & 1.6 \\
\hline
\end{tabular}

versely, $\mathrm{Fe}, \mathrm{Zn}$ and $\mathrm{Cu}$ concentrations in fruit bodies were lower than those in the mycelium.

These results indicated that the translocations of $\mathrm{Cs}$ and coexisting elements from the mycelium to the fruit bodies in $H$. vinosophyllum had three different patterns. Cs, $\mathrm{K}$ and $\mathrm{P}$ were mostly translocated to fruit bodies while most of $\mathrm{Fe}, \mathrm{Zn}$ and $\mathrm{Cu}$ were kept in the mycelium. $\mathrm{Ca}$ and $\mathrm{Mg}$ were not translocated from the mycelium to the fruit bodies. The results also showed that in $H$. vinosophyllum, the uptake of Cs might have a similar pattern to that of $\mathrm{K}$ and $\mathrm{P}$.

The accumulation of $\mathrm{Fe}, \mathrm{Zn}$ and $\mathrm{Cu}$ in the fruit bodies with the high transfer factors (34.3, 87.6 and $51.7 \mathrm{~L} / \mathrm{kg}$ dry, respectively) in $H$. vinosophyllum also implies that this fungus would be a suitable bioindicator of the environmental heavy metal pollution. Besides, in the control of heavy metal in ecosystems, the keeping of $\mathrm{Fe}, \mathrm{Zn}$ and $\mathrm{Cu}$ in the mycelium would be attended.

Ban-nai et al. ${ }^{4), 22)}$ reported that in $H$. vinosophyllum fruit bodies, the transfer factors of ${ }^{137} \mathrm{Cs}$ and ${ }^{85} \mathrm{Zn}$ were 21 and $15-30$, respectively. Whereas, those of $\mathrm{Cs}$ and $\mathrm{Zn}$ in the fruit bodies in this study are 50.2 and 87.6, respectively. According to Duff and Ramsey ${ }^{27)}$, some conditions such as $\mathrm{pH}$, organic matter content and pre- ferred growth medium probably have the effects on the accumulation of $\mathrm{Cs}$ as well as other radionuclides by mushroom. Therefore, our results might be caused by the higher fruiting ability which derived from the suitable concentration of $\mathrm{NH}_{4}{ }^{+}$for this ammonia fungus (unpublished data).

$3 \cdot 2$ The effect of $\mathrm{NH}_{4}{ }^{+}$concentrations on the caesium, potassium and phosphorus uptake by Hebeloma vinosophyllum

The results of the above experiment showed that in $\mathrm{H}$. vinosophyllum, the uptake of $\mathrm{Cs}$ might have a similar pattern to that of $\mathrm{K}$ and $\mathrm{P}$. Therefore, the effect of $\mathrm{NH}_{4}{ }^{+}$concentrations on the uptake of $\mathrm{Cs}, \mathrm{K}$ and $\mathrm{P}$ were investigated.

The transfer factors of $\mathrm{Cs}$ and $\mathrm{K}$ in the mycelium and the fruit bodies decreased according to the increment of $\mathrm{NH}_{4}{ }^{+}$concentration while that of $\mathrm{P}$ varied with different $\mathrm{NH}_{4}{ }^{+}$concentrations (Fig. $2 \mathrm{~A}-\mathrm{C}$ ). It means that the high concentration of $\mathrm{NH}_{4}{ }^{+}$might affect to the uptake of both $\mathrm{Cs}$ and $\mathrm{K}$ as the competitor but not to that of $\mathrm{P}$ in $H$. vinosophyllum.

Besides, $H$. vinosophyllum formed fruit bodies in $\mathrm{NH}_{4}{ }^{+} 177 \mathrm{mg} / \mathrm{L}, 590 \mathrm{mg} / \mathrm{L}$ and $1770 \mathrm{mg} / \mathrm{L}$ (Figs. 3, 4). The highest dry weight of the fruit bodies was obtained at $177 \mathrm{mg} \mathrm{NH}_{4}{ }^{+} / \mathrm{L}$ (Fig. 3 A and Fig. 4). The immature fruit bodies which 

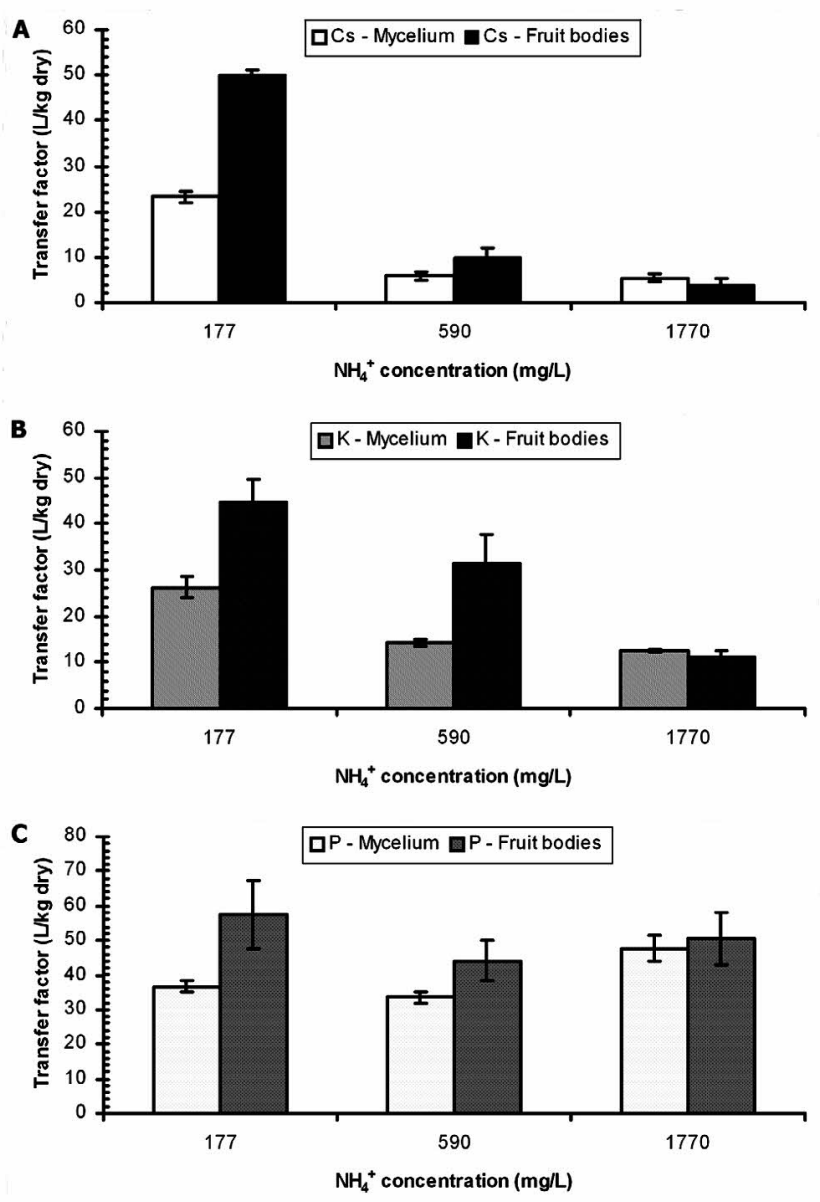

Fig. 2 The transfer factors of $\mathrm{Cs}(\mathrm{A}), \mathrm{K}(\mathrm{B})$ and $\mathrm{P}(\mathrm{C})$ in Hebeloma vinosophyllum biomass (mycelium and fruit bodies) under different $\mathrm{NH}_{4}{ }^{+}$concentrations. Mean \pm standard deviation (vertical bar).

had unexpanded cap without gills formed at $1770 \mathrm{mg} / \mathrm{L} \mathrm{NH}_{4}{ }^{+}$(Fig. $3 \mathrm{C}$ ).

Muramatsu et $\mathrm{al}^{28)}$ and Baeza et al. ${ }^{29)}$ reported the influence of the maturity of fruit bodies on radionuclide uptake. Our results showed that the concentration of $\mathrm{NH}_{4}{ }^{+}$might affect to the fruit body formation of $H$. vinosophyllum. Hence, the uptake of $\mathrm{Cs}$ and $\mathrm{K}$ in $\mathrm{H}$. vinosophyllum could depend on the condition of the fruit body formation.

According to Yoshida and Muramatsu ${ }^{2}$, Cs was not correlated with $\mathrm{K}$ in mushrooms collected from a pine forest in Tokai-mura, Ibaraki, Japan $(r=0.37)$. They suggested that the mechanism of Cs uptake was different from that of $\mathrm{K}$ uptake. In this study, the ratios of $\mathrm{Cs}$ and $\mathrm{K}$ concentrations in both the mycelium and the fruit bodies decreased when the concentration of $\mathrm{NH}_{4}{ }^{+}$increased (Fig. 5). This result indicates that the addition of $\mathrm{NH}_{4}{ }^{+}$affected more the uptake of Cs than that of $\mathrm{K}$, suggesting that a part of Cs might be taken up by similar 

ammonium ion as a competitor, by laboratory experiments using Hebeloma vinosophyllum -
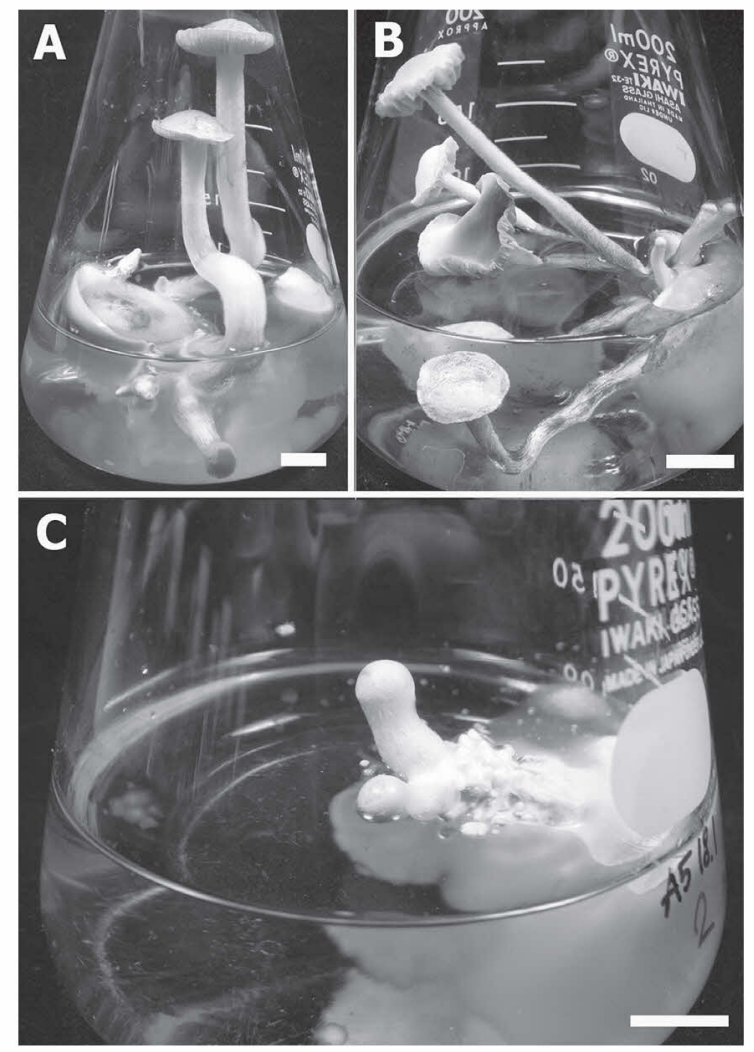

Fig. 3 Fruit body formation of Hebeloma vinosophyllum in different $\mathrm{NH}_{4}{ }^{+}$concentrations. A : $177 \mathrm{mg} / \mathrm{L}, \mathrm{B}$ : $590 \mathrm{mg} / \mathrm{L}$ and C : $1770 \mathrm{mg} / \mathrm{L} . \mathrm{Bar}=10 \mathrm{~mm}$.

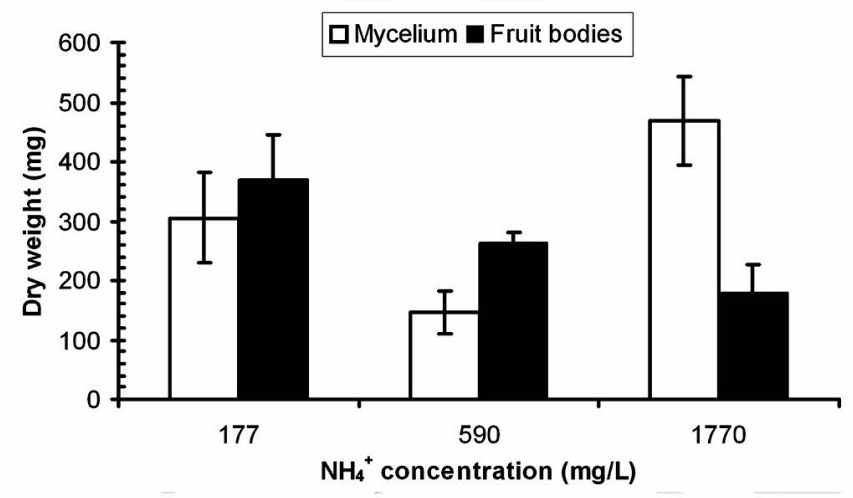

Fig. 4 Dry biomass of Hebeloma vinosophyllum (mycelium and fruit bodies) in different $\mathrm{NH}_{4}{ }^{+}$concentrations. Mean \pm standard deviation (vertical bar). 


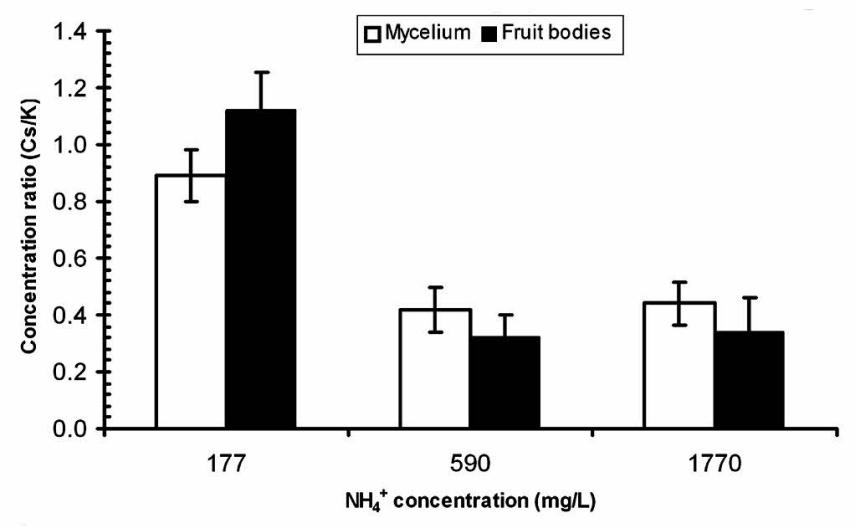

Fig. 5 The ratios of $\mathrm{Cs}$ and $\mathrm{K}$ concentrations in mycelium and fruit bodies of Hebeloma vinosophyllum in different $\mathrm{NH}_{4}{ }^{+}$concentrations. Mean \pm standard deviation (vertical bar).

mechanism as $\mathrm{NH}_{4}{ }^{+}$rather than $\mathrm{K}$. The result provides one of the possible explanations why Cs was not correlated with $\mathrm{K}$ in the field observation by Yoshida and Muramatsu²).

Steiner et al. $^{30)}$ and Harbhajan ${ }^{31)}$ discussed mycorrhizal fungi using as bioremediation in the control of radionuclides in forest ecosystems. Vinichuk et al ${ }^{32)}$ investigated the effect of arbuscular mycorrhizal fungi in radiocaesium uptake by plants. As a putative ectomycorrhizal fungus ${ }^{33}$, Hebeloma vinosophyllum would be an excellent model fungus for the investigation of caesium accumulation in ectomycorrhizal fungi. The further research is required to understand the uptake of caesium among $H$. vinosophyllum mycelium, fruit bodies and its ectomycorrhizal host plant Pinus spp. and Quercus spp. Belonging to ammonia fungi ${ }^{34)}$, this fungus occurs at high frequency after urea treatment to the forest floor. Therefore by urea application to the forest floor and using ectomycorrhizal symbiosis of $H$. vinosophyllum Pinus spp. and/or Quercus spp., the efficient control of radiocaesium in the field could be expected.

\section{Conclusion}

The ectomycorrhizal ammonia fungus Hebeloma vinosophyllum absorbed caesium and coexisting elements ( $\mathrm{K}, \mathrm{Ca}, \mathrm{Mg}, \mathrm{Zn}, \mathrm{Cu}, \mathrm{Fe}$ and P) with the high transfer factors. These eight analyzed elements were translocated from mycelium to fruit bodies in three different patterns. Cs, $\mathrm{K}$ and $\mathrm{P}$ were mostly translocated to the fruit bodies while most of $\mathrm{Fe}, \mathrm{Zn}$ and $\mathrm{Cu}$ were kept in the mycelium. $\mathrm{Ca}$ and $\mathrm{Mg}$ were not translocated between the mycelium and the fruit bodies. The highest translocation from the mycelium to the fruit bodies was observed in Cs among eight analysed elements.

The uptake of Cs might have a similar pattern to those of $\mathrm{K}$ and $\mathrm{P}$. However, the high concentration of $\mathrm{NH}_{4}{ }^{+}$might also affect as the competitor to the uptake of both $\mathrm{Cs}$ and $\mathrm{K}$, but not to that of P. Besides, the addition of $\mathrm{NH}_{4}{ }^{+}$ affected more the uptake of $\mathrm{Cs}$ than that of $\mathrm{K}$. All these results contribute to clearer understanding the caesium uptake by ectomycorrhizal fungi under competition of coexisting elements in the environment. $H$. vinosophyllum 
would be an excellent model fungus for the investigation of caesium accumulation in ectomycorrhizal fungi in laboratory condition (in vitro).

\section{References}

1) Haselwandter, K., Health Phys., 34, 713-715(1978)

2) Yoshida, S. and Muramatsu, Y., J. Environ. Radioactivity, 41, 183-205(1998)

3) Kuwahara, C., Fukumoto, A., Ohsone, A., Furuya, N., Shibata, H., Sugiyama, H. and Kato, F., Sci. Total Environ., 245, 165-173(2005)

4) Ban-nai, T., Yoshida, S. and Muramatsu, Y., $R A$ DIOISOTOPES, 43, 77-82(1994)

5) Tsukuda, H., Shibata, H. and Sugiyama, H., J. Environ. Radioactivity, 39, 149-160(1998)

6) Yoshida, S. and Muramatsu, Y., Sci. Total Environ., 157, 197-205(1994)

7) Teherani, D. K., J. Radioanal . Nucl. Chem., 117, 6974(1987)

8) Byrne, A. R., J. Environ. Radioactivity, 6, 177-183 (1988)

9) Haselwandter, K., Berreck, M. and Brunner, P., Trans. Br. Mycol. Soc., 90, 171-174(1988)

10) Baldini, E., Bettoli, M. G. and Tubertini, O., Radiochim. Acta., 46, 143-144(1989)

11) Borio, R., Chiocchini, S., Cicioni, R., Esposti, P. D., Rongoni, A., Sabatini, P., Scampoli, P., Antonini, A. and Salvadori, P., Sci. Total Environ., 106, 183-190 (1991)

12) Yamagata, N., Matsuda, S. and Chiba, M., J. Rad. Res., 10, 107-112(1969)

13) Heinrich, G., Radiat. Environ. Biophysics, 31, 39-49 (1992)

14) Sugiyama, H., Shibata, H., Isomura, K. and Iwashima, K., J. Food Hygienic Soc. Japan, 35, 1322(1994)

15) Dighton, J., Clint, G. M. and Poskitt, J., Mycol . Res., 95, 1052-1056 (1991)

16) Yoshida, S., Muramatsu, Y. and Ogawa, M., J. Environ. Radioactivity, 22, 141-154(1994)

17) Guillitte, O., Melin, J. and Wallberg, L., Sci. Total
Environ., 157, 207-215(1994)

18) Brückmann, A. and Wolters, V., Sci. Total Environ., 157, 249-256 (1994)

19) Rühm, W., Yoshida, S., Muramatsu, Y., Steiner, M. and Wirth, E., J. Environ. Radioactivity, 45, 253-270 (1999)

20) Yoshida, S., Muramatsu, Y., Steiner, M., Belli, M., Pasquale, A., Rafferty, B., Rühm, W., Rantavaara, A., Linkov, I., Dvornik, A. and Zhuchenko, T., $R \boldsymbol{a}$ dioprotection-Colloques, 37, C1-391-C1-396(2001)

21) Yoshida, S., Muramatsu, Y., Dvornik, A., Zhuchenko, T. and Linkov, I., J. Environ. Radioactivity, 75, 301-313(2004)

22) Ban-nai, T., Yoshida, S., Muramatsu, Y. and Suzuki, A., J. Nucl. Radiochem. Sci., 6, 111-113 (2005)

23) Terada, H., Shibata, H., Kato, F. and Shigiyama, H., J. Radioanal. Nucl. Chem., 235, 195-200(1998)

24) Ho, B. T. Q., Pham, N. D. H., Shimuzu, K., Fukiharu, T, Truong, B. N. and Suzuki, A., Mycotaxon (submitted in 2012)

25) Ohta, A., Trans. Mycol.Soc. Jpn, 31, 323-334(1990)

26) Yoshida, S. and Muramatsu, Y., Intern. J. Environ. Anal. Chem., 67, 49-58(1997)

27) Duff, M. C. and Ramsey, M. L., J. Environ. Radioactivity, 99, 912-932(2008)

28) Muramatsu, Y., Yoshida, S. and Sumiya, M., Sci. Total Environ., 105, 29-39 (1991)

29) Baeza, A., Guillén, F. J., Salas, A. and Manjón, J. L., Sci. Total Environ., 359, 255-266 (2006)

30) Steiner, M., Linkov, I., and Yoshida, S., J. Environ. Radioactivity, 58, 217-241 (2002)

31) Harbhajan, S., Mycoremediation: Fungal Bioremadiation, pp. 533-572, John Wiley \& Son, Inc., Hoboken, New Jersey (2006)

32) Vinichuk, M., Martenson, A., Ericsson, T. and Rosen, K., J . Environ . Radioactivity, 115, 151-156 (2013)

33) Imamura, A. and Yumoto, T., Mycoscience, 49, 4255(2008)

34) Sagara, N., Contr. Biol. Lab. Kyoto Univ., 24, 205276,7 pls. (1975) 